\title{
Sequence-selective Peptide-binding Metallomacrocycles
}

\author{
Kum Hee Lee and Seung Soo Yoon \\ Department of Chemistry, SungKytmKinan University, Sunon 440-746, Korea. "E-mait: ssyoon(achem.skkuac.kr \\ Recened August 17, 2005
}

Key Words : Molecular recognition, Metallomacrocycle, Peptide-binding

Since the pioneering work' of Pederson, Cram and Lehn, many molecular receptors capable of interacting selectively with various substrates have been described. ${ }^{2}$ Particularly, the development of peptide-binding receptors ${ }^{3}$ is of great interest because of its relevance to peptide-protein recognition processes in biological systems.

Recently, self-assembly by exploiting noncovalent interactions such as metal-ligand coordinate bond is emerging as a novel strategy in construction of peptide-binding synthetic molecules. ${ }^{4}$

Here, as the continuing efforts to develop selective peptide-binding receptors, novel $\mathrm{C}_{2}$-symmetric metallomacrocycles are described.

Syntheses of receptors 1-4 began with the preparation of

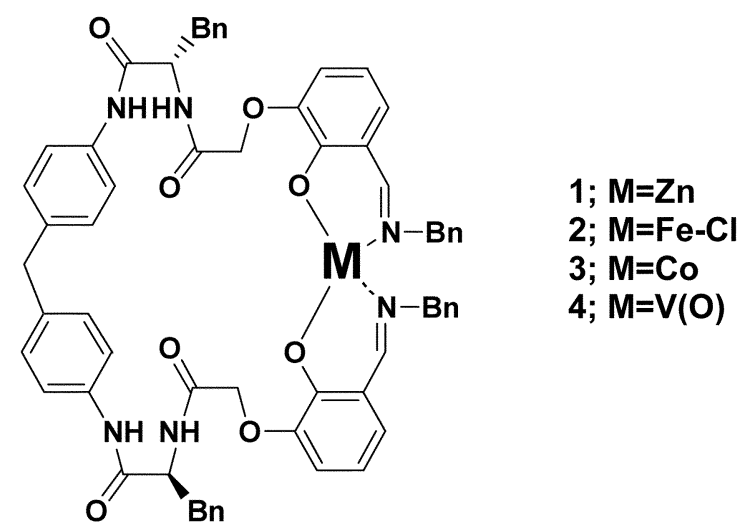

Figure 1. Structures of Metallomacrocycles (1-4). the flexible ligand (9), as shown in Scheme 1. DlC-promoted amide coupling reaction between N-Boc-(L)-phenylalanine and 4,4'-methylenedianiline provided the starting material 5. DM $\triangle P$-catalyzed amide coupling reaction between Boc-deprotected bis-amine of $\mathbf{5}$ and bis-pentafluorophenyl ester $6,{ }^{5}$ and the subsequent deprotection of allyl groups and imine formation with benzyl amine provided the ligand 9. Metallomacrocycles (1-4) were prepared by mixing ligand 9 and the corresponding metal chloride, acetate or acetoacetonate in ethanol, stirring for $12 \mathrm{hrs}$ under reflux conditions with $55,52,49$ and $45 \%$, respectively.

The products. metal complexes (1-4) are air-stable and moisture-insensitive, and the structures of 1-4 were established by mass spectrum. 'H NMR spectroscopy, IR and UV spectroscopy.

Recently, combinatorial chemistry has become a major tool in the elucidation of the binding properties of receptors." Receptor 2 has the distinct red color due to transition metal jon (Fe(lll)), and thus ideal for solid phase color binding assay using encoded combinatorial library of peptide substrates.

Receptor 2 was screened against a tripeptide library on hydrophobic polystyrene in $\mathrm{CHCl}_{3}{ }^{7}$. The library was prepared by encoded split synthesis and has the general structure Ac-AA3-AA2-AAl-NH( $\left(\mathrm{CH}_{2}\right)_{6}-\mathrm{C}(\mathrm{O}) \mathrm{NH}-\mathrm{Poly}-$ styrene." Decoding the tripeptides on the colored beads by using electron capture gas chromatography revealed selective peptides-binding properties of receptor (2). The most tightly binding substrates with macrocyclic compounds (2) are shown in Table 1.

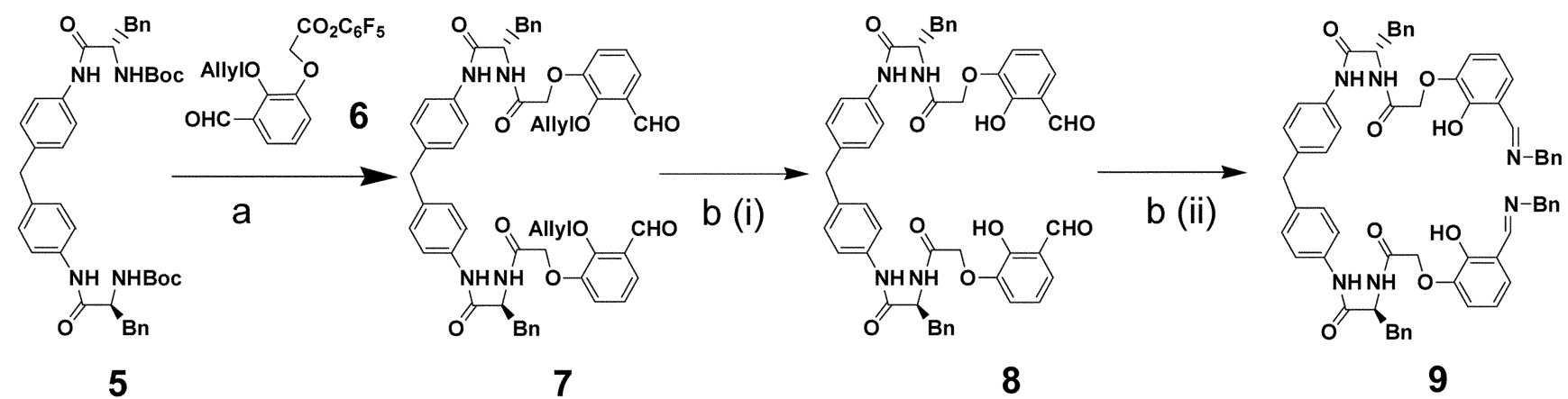

$$
\stackrel{\mathrm{C}}{\longrightarrow} 1,2,3,4
$$

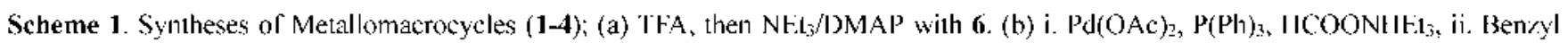
amine in EtOIl. (c) reflux in EtOJI with $\mathrm{Zn}(\mathrm{OAc})_{2}$ for $1, \mathrm{FeCl}_{3}$ for $2, \mathrm{Co}(\mathrm{OAc})_{2}$ for 3 and $\mathrm{V}(\mathrm{O})(\mathrm{acac})_{2}$ for 4. 
Table 1. Sequences (Resin-AA1-AA2-AA3-Ac) selected by binding assay with receptor (2)

\begin{tabular}{rlllll}
\hline Entry & & & \multicolumn{1}{c}{ Entry } & \\
\cline { 1 - 2 } \cline { 5 - 6 } & (L)Ala-(D)Leu-(L)Ala & & 2 & (L)Ala-(L)Lys-(L)Leu \\
3 & (L)Ala-(D)Leu-(L)Ala & & 4 & (D)Phe-(D)Leu-(L)Ala \\
5 & (L)Asp-(L)Lys-(L)Leu & & 6 & (L)Ala-(D)Leu-(L)Asn \\
7 & (D)Val-Gly-(D)Asn & & 8 & (D)Val-(L)Lys-(L)Asn \\
9 & (L)Asp-(L)Lys-(L)Leu & & 10 & (D)Val-(L)Lys-Gly \\
11 & (L)Leu-(D)Leu-Gly & & 12 & (L)His-(D)Leu-(L)Ser \\
13 & (L)Val-(L)Lys-(L)Ser & & 14 & (L)Ala-(L)Lys-(L)Asn \\
15 & (L)Val-(L)Lys-(L)Ala & & \\
\hline
\end{tabular}

Table 2. Binding of 2 and Peptides in $\mathrm{CHCl}_{3}$

\begin{tabular}{cc}
\hline \multicolumn{1}{c}{ Peptide } & $\begin{array}{c}\text { Binding Energy } \\
\text { (kcal/mol) }\end{array}$ \\
\hline Polymer-(L)Ala-(D)Leu-(L)Ala-Ac & -4.45 \\
Polymer-(L)Ala-(D)Leu-(L)Asn-Ac & -4.58 \\
Polymer-(D)Val-(D)Leu-(L)Ala-Ac & -4.74 \\
Polymer-(D)Val-(D)Leu-(L)Asn-Ac & -4.86 \\
Polymer-Gly-Gly-Gly-Ac & $<-0.5$ \\
\hline
\end{tabular}

The binding data in Table 1 reveal a number of notable trends. For example, receptor 2 was found to bind strongly with the substrate with (L)Ala (5/15), (D)Leu and (L)Lys (6/ 15and 7/15) and, (L)Ala and (L)Asn (4/15 and 3/15) at AAl, $\mathrm{AA} 2$ and $\mathrm{AA} 3$ positions, respectively.

To confirm the findings and to estimate the energetic extents of the selectivities observed, several peptides were resynthesized and their association with 2 measured in $\mathrm{CHCl}_{3}{ }^{9}$ The results are summarized in Table 2 . The binding energies were found to be $-4.45 \sim-4.86 \mathrm{kcal} / \mathrm{mol}$. The other substrates found by binding assay are expected to have the similar range of binding energies. The binding energy with Polymer-Gly-Gly-Gly-Ac, which was not bound with receptor 2 in assay, was found to be both less than $-0.5 \mathrm{kcal} /$ mol.

To test the notion that the modification of the shape of artificial recognition sites using the different metal ions in metallomacrocycles can allow to change the peptide-binding properties of artificial receptors, a polypeptide was synthesized and its association with 1-4 were measured in $\mathrm{CHCl}_{3}$. The results are summarized in Table 3 .

The binding data in Table 3 showed clearly that the subtle changes in the coordination number and geometry of different metals can affect markedly the peptide-binding

Table 3. Binding of 1-4 and Peptide in $\mathrm{CHCl}_{3}$

\begin{tabular}{lcc}
\hline \multicolumn{1}{c}{ Peptide } & Receptor & $\begin{array}{c}\text { Binding Energy } \\
\text { (kcal/mol) }\end{array}$ \\
\hline & $\mathbf{1}$ & $\sim 0$ \\
Polymer-(D)Val-(D)Leul- & $\mathbf{2}$ & -4.74 \\
(L)Ala-Ac & $\mathbf{3}$ & -3.15 \\
& $\mathbf{4}$ & -2.91 \\
\hline
\end{tabular}

properties of metallomacrocyclic receptors. For example, these data showed that the changes in metal ion from Fe(III) to $\mathrm{Zn}$ (II) reduce the binding energies by $\sim 4.7 \mathrm{kcal} / \mathrm{mol}$. Also, changes in metal ion from $\mathrm{Fe}$ (III) to $\mathrm{Co}$ (II), V(IV) reduce the binding energies by 1.5 and $1.8 \mathrm{kcal} / \mathrm{mol}$, respectively.

In conclusion, receptor-like molecules with the well-defined binding cavity were successfully prepared by exploiting coordinate bond between transition metal and ligands. Furthermore, combinatorial binding studies revealed that these metal-templated self-assembling receptors have the highly selective peptide-binding properties. Further studies on the structures of complexes between receptors and peptide substrates, and the peptide-binding properties of the other related synthetic receptors are in progress in this laboratory.

\section{Experimental Section}

Synthesis of 5. To solution of $1.54 \mathrm{~g}$ of N-Boc-(L)phenylalanine $(5.800 \mathrm{mmol})$ in $6 \mathrm{~mL}$ of dichloromethane were added $0.5 \mathrm{~g}$ of $4,4^{\prime}$-methylenedianiline $(2.052 \mathrm{mmol})$, $0.783 \mathrm{~g}$ of HOBT $(5.800 \mathrm{mmol})$ and $0.91 \mathrm{~mL}$ of DIC $(5.800$ mmol) at $0^{\circ} \mathrm{C}$. After the stirring for $5 \mathrm{hr}$ at room temperature, all volatiles were removed at reduced pressure. The mixture was dissolved in dichloromethane and organic layers was washed with $1 \mathrm{M} \mathrm{HCl}$, saturated $\mathrm{NaHCO}_{3}$, and brine and dried with $\mathrm{MgSO}_{4}$. The residue was purified by flash chromatography on silica gel using $20 \%$ ethyl acetate in hexane to give 5 as an amorphous white solid $(1.13 \mathrm{~g}$, $65 \%):{ }^{1} \mathrm{H} \mathrm{NMR}\left(\mathrm{CDCl}_{3}\right) \delta(\mathrm{ppm}) 9.20(\mathrm{br}, 2 \mathrm{H}), 7.46(\mathrm{~m}$, $4 \mathrm{H}), 7.19(\mathrm{~m}, 4 \mathrm{H}), 7.12(\mathrm{~m}, 6 \mathrm{H}), 7.01(\mathrm{~m}, 4 \mathrm{H}), 6.05(\mathrm{br}, 2 \mathrm{H})$, $4.82(\mathrm{br}, 2 \mathrm{H}), 3.91(\mathrm{~s}, 2 \mathrm{H}), 3.07(\mathrm{~m}, 4 \mathrm{H}), 1.32(\mathrm{~s}, 18 \mathrm{H})$.

To a solution of $0.4 \mathrm{~g}$ of $5(0.577 \mathrm{mmol})$ in $8 \mathrm{~mL}$ of dichloromethane was slowly added $2 \mathrm{~mL}$ of TFA. After stirring for $4 \mathrm{hr}$ at room temperature, all volatiles were removed at reduced pressure. The crude di-TFA salts of 5 were used the next reaction without further purification.

Synthesis of 7. To solution of $0.4 \mathrm{~g}$ of the di-TFA salts of amine intermediate $(0.577 \mathrm{mmol})$ and $0.58 \mathrm{~g}$ of the pentafluorophenylester $6(1.443 \mathrm{mmol})$ in $7 \mathrm{~mL}$ of DMA was added $0.14 \mathrm{~g}$ of DMAP $(1.155 \mathrm{mmol})$ and $0.6 \mathrm{~mL}$ of DIEA (3.462 mmol) at $0{ }^{\circ} \mathrm{C}$. After the stirring for $18 \mathrm{hr}$ at room temperature, all volatiles were removed at reduced pressure. The residue was purified by flash chromatography on silica gel using $4 \% \mathrm{MeOH}$ in dichloromethane to give bis-allyl protected intermediate of 7 as an amorphous white solid $(0.26 \mathrm{~g}, 49 \%):{ }^{1} \mathrm{H}$ NMR $\left(\mathrm{DMSO}-\mathrm{d}_{6}\right) \delta(\mathrm{ppm}) 10.28(\mathrm{~s}, 2 \mathrm{H})$, $10.13(\mathrm{~s}, 2 \mathrm{H}), 8.37(\mathrm{~d}, J=8.0 \mathrm{~Hz}, 2 \mathrm{H}), 7.47(\mathrm{~m}, 4 \mathrm{H}), 7.24$ $(\mathrm{m}, 10 \mathrm{H}), 7.18(\mathrm{~m}, 2 \mathrm{H}), 7.14(\mathrm{~m}, 4 \mathrm{H}), 7.06(\mathrm{~m}, 4 \mathrm{H}), 6.05(\mathrm{~m}$, $2 \mathrm{H}), 5.31$ (d, $J=17.0 \mathrm{~Hz}, 2 \mathrm{H}), 5.19$ (d, $J=10.5 \mathrm{~Hz}, 2 \mathrm{H}$ ), $4.77(\mathrm{~m}, 2 \mathrm{H}), 4.64(\mathrm{~m}, 8 \mathrm{H}), 3.83(\mathrm{~s}, 2 \mathrm{H}), 3.10(\mathrm{~m}, 2 \mathrm{H}), 2.89$ (m, 2H).

Synthesis of 8. To solution of $0.138 \mathrm{~g}$ of bis-allyl protected compound $7(0.149 \mathrm{mmol})$ and $0.6 \mathrm{~mL}$ of DIEA (3.462 mmol) in $20 \mathrm{~mL}$ of $\mathrm{MeOH}$ were added palladium acetate $3.33 \mathrm{mg}$ ( $10 \mathrm{~mol} \%$ ), triphenyl phosphine $15.58 \mathrm{mg}$ (40 $\mathrm{mol} \%)$, TEA $0.124 \mathrm{~mL}(0.891 \mathrm{mmol})$, and formic acid 
$0.034 \mathrm{~mL}(0.891 \mathrm{mmol})$ and refluxed for $3 \mathrm{hr}$ under a nitrogen atmosphere. The solution was acidified with $1 \mathrm{M}$ $\mathrm{HCl}$ and extracted with dichloromethane. The crude products were diluted with dichloromethane to give $\mathbf{8}$ as an amorphous white solid (74 $\mathrm{mg}, 59 \%$ ) that were collected by filtration: ${ }^{1} \mathrm{H}$ NMR (DMSO-d $\left.\mathrm{d}_{6}\right) \delta(\mathrm{ppm}) 10.40(\mathrm{~s}, 2 \mathrm{H}), 10.38$ $(\mathrm{s}, 2 \mathrm{H}), 10.16(\mathrm{~s}, 2 \mathrm{H}), 8.75$ (d, $J=8.5 \mathrm{~Hz}, 2 \mathrm{H}), 7.49$ (d, $J=$ $5.0 \mathrm{~Hz}, 4 \mathrm{H}), 7.29(\mathrm{~m}, 5 \mathrm{H}), 7.22(\mathrm{~m}, 5 \mathrm{H}), 7.12(\mathrm{~m}, 8 \mathrm{H}), 6.81$ $(\mathrm{m}, 2 \mathrm{H}), 4.82(\mathrm{~m}, 2 \mathrm{H}), 4.56(\mathrm{~d}, J=15.0 \mathrm{~Hz}, 2 \mathrm{H}), 4.48(\mathrm{~d}, J=$ $15.0 \mathrm{~Hz}, 2 \mathrm{H}), 3.83(\mathrm{~s}, 2 \mathrm{H}), 3.13(\mathrm{~m}, 2 \mathrm{H}), 2.93(\mathrm{~m}, 2 \mathrm{H})$.

Synthesis of 9. To a solution of $0.2 \mathrm{~g}$ of $8(0.236 \mathrm{mmol})$ in $40 \mathrm{~mL}$ of $\mathrm{EtOH}: \mathrm{DMF}(1: 1)$ was added $0.059 \mathrm{~mL}$ of benzylamine $(0.542 \mathrm{mmol})$. After refluxing for $14 \mathrm{hr}$ under a nitrogen atmosphere, the crude products precipitated by adding ethyl ether. The crude products were recrystallized from EtOH/ethyl ether to give 9 as an amorphous yellow solid (184 mg, 76\%): ${ }^{1} \mathrm{H}-\mathrm{NMR}$ (DMSO-d 6 ) $\delta$ (ppm) 13.80 (br, $2 \mathrm{H}), 10.07(\mathrm{~s}, 2 \mathrm{H}), 8.71(\mathrm{~s}, 2 \mathrm{H}), 8.27(\mathrm{~d}, J=8.5 \mathrm{~Hz}, 2 \mathrm{H})$, $7.46(\mathrm{~d}, J=6.5 \mathrm{~Hz}, 4 \mathrm{H}), 7.36(\mathrm{~m}, 10 \mathrm{H}), 7.24(\mathrm{~m}, 2 \mathrm{H}), 7.19$ $(\mathrm{m}, 8 \mathrm{H}), 7.10(\mathrm{~m}, 10 \mathrm{H}), 4.82(\mathrm{~s}, 4 \mathrm{H}), 4.74(\mathrm{~m}, 2 \mathrm{H}), 4.48(\mathrm{~m}$ $4 \mathrm{H}), 3.83(\mathrm{~s}, 2 \mathrm{H}) 3.06(\mathrm{~m}, 2 \mathrm{H}), 2.87(\mathrm{~m}, 2 \mathrm{H}) ;{ }^{13} \mathrm{C}-\mathrm{NMR}$ $\left(\mathrm{DMSO}-\mathrm{d}_{6}\right) \delta$ (ppm) 39.043, 41.163, 55.368, 62.263, $69.551,118.697,119.184,119.959,120.759,125.795$, $127.581,128.422,128.892,129.259,129.771,130.051$, $130.340,137.739,137.780,138.321,139.579,147.848$, $153.886,167.513,168.973,170.524$; IR (KBr) 1659, 1632, $1521,1467,1438 \mathrm{~cm}^{-1}$; MS (FAB) $\mathrm{m} / \mathrm{z}=1027(\mathrm{MH})^{+}$.

Synthesis of 1 . To a solution of $50 \mathrm{mg}$ of $9(0.0487 \mathrm{mmol})$ in $40 \mathrm{~mL}$ of dichloromethane : $\mathrm{MeOH}(1: 1)$ was added $10.68 \mathrm{mg}$ of zinc(II) acetate dihydrate $(0.0487 \mathrm{mmol})$. After refluxing for $18 \mathrm{hr}$ under a nitrogen atmosphere, all volatiles were removed at reduced pressure. The crude products were recrystallized from dichloromethane/hexane to give $\mathbf{1}$ as an amorphous white yellow solid $(29 \mathrm{mg}, 55 \%)$ : 'H NMR $\left(\mathrm{DMSO}-\mathrm{d}_{6}\right) \delta(\mathrm{ppm}) 9.95(\mathrm{~m}, 2 \mathrm{H}), 8.37(\mathrm{~s}, 2 \mathrm{H}), 8.26(\mathrm{~d}, J=$ $8.5 \mathrm{~Hz}, 2 \mathrm{H}), 7.37(\mathrm{~m}, 6 \mathrm{H}), 7.18(\mathrm{~m}, 10 \mathrm{H}), 7.06(\mathrm{~m}, 10 \mathrm{H})$, $6.87(\mathrm{~m}, 6 \mathrm{H}), 6.33(\mathrm{~m}, 2 \mathrm{H}), 4.65(\mathrm{~d}, J=5.5 \mathrm{~Hz}, 2 \mathrm{H}), 4.41$ $(\mathrm{m}, 4 \mathrm{H}), 4.26(\mathrm{~m}, 4 \mathrm{H}), 3.79(\mathrm{~m}, 2 \mathrm{H}), 2.99(\mathrm{~m}, 2 \mathrm{H}), 2.85(\mathrm{~m}$, $2 \mathrm{H}$ ); ${ }^{13} \mathrm{C}-\mathrm{NMR}$ (DMSO-d $) \delta$ (ppm) $31.377,38.479,54.995$, $63.902,70.505,113.604,119.611,120.291,126.938$, $128.289,128.677,129.013,129.158,129.516,129.586$, $129.772,129.887,130.540,137.174,137.310,137.809$, $137.889,151.227,162.265,169.314,170.025$; IR 1658 , $1619,1543,1514 \mathrm{~cm}^{-1}$; UV/Vis $\left(\mathrm{CH}_{2} \mathrm{Cl}_{2}\right.$ soln) $327,370 \mathrm{~nm}$; $\mathrm{MS}(\mathrm{FAB}) \mathrm{m} / \mathrm{z}=1089(\mathrm{MH})^{+}$.

Synthesis of 2. To a solution of $50 \mathrm{mg}$ of $9(0.0487 \mathrm{mmol})$ in $48 \mathrm{~mL}$ of $\mathrm{MC}: \mathrm{MeOH}(1: 1)$ was added $13.15 \mathrm{mg}$ of iron(III) chloride $(0.0487 \mathrm{mmol})$. After refluxing for $18 \mathrm{hr}$ under a nitrogen atmosphere, all volatiles were removed at reduced pressure. The crude products were recrystallized from dichloromethane to give $\mathbf{2}$ as an amorphous brown solid $(28 \mathrm{mg}, 52 \%$ ) that were collected by filtration: IR $1658,1608,1541,1516,1215 \mathrm{~cm}^{-1}$; UV/Vis $\left(\mathrm{CH}_{2} \mathrm{Cl}_{2}\right.$ soln $)$ $333,520 \mathrm{~nm}$; MS (FAB) $m / z=1081 \mathrm{M}^{+}$.
Synthesis of 3. To a solution of $50 \mathrm{mg}$ of $9(0.0487 \mathrm{mmol})$ in $40 \mathrm{~mL}$ of $\mathrm{MC}: \mathrm{MeOH}(1: 1)$ was added $10.54 \mathrm{mg}$ of cobalt(II) acetate tetrahydrate $(0.0487 \mathrm{mmol})$. After refluxing for $18 \mathrm{hr}$ under a nitrogen atmosphere, all volatiles were removed at reduced pressure. The crude products were recrystallized from dichloromethane/ethyl ether to give $\mathbf{3}$ as an amorphous green solid (26 mg, $49 \%$ ): IR 1664, 1615 , $1516,1444 \mathrm{~cm}^{-1}$; UV/Vis $\left(\mathrm{CH}_{2} \mathrm{Cl}_{2}\right.$ soln $) 303,380 \mathrm{~nm}$; MS (FAB) $\mathrm{m} / \mathrm{z}=1084(\mathrm{MH})^{+}$.

Synthesis of 4. To a solution of $50 \mathrm{mg}$ of $9(0.0487 \mathrm{mmol})$ in $40 \mathrm{~mL}$ of $\mathrm{MC}: \mathrm{MeOH}(1: 1)$ was added $12.9 \mathrm{mg}$ of vanadyl acetylacetate $(0.0487 \mathrm{mmol})$. After refluxing for 18 hr under a nitrogen atmosphere, all volatiles were removed at reduced pressure. The crude products were dissolved in EtOH and obtained after evaporating from solvent to give 4 as an amorphous green solid $(23 \mathrm{mg}, 45 \%)$ : 'H NMR (DMSO-d $\left.\mathrm{d}_{6}\right) \delta(\mathrm{ppm}) 10.15(\mathrm{~d}, J=15.5 \mathrm{~Hz}, 2 \mathrm{H}), 8.60(\mathrm{~s}, 2 \mathrm{H})$, $8.30(\mathrm{~d}, J=8.5 \mathrm{~Hz}, 2 \mathrm{H}), 7.49(\mathrm{~m}, 8 \mathrm{H}), 7.32(\mathrm{~m}, 8 \mathrm{H}), 7.21$ $(\mathrm{m}, 8 \mathrm{H}), 7.16(\mathrm{~m}, 4 \mathrm{H}), 7.02(\mathrm{~d}, J=3.5 \mathrm{~Hz}, 2 \mathrm{H}), 6.97(\mathrm{~d}, J=$ $3.5 \mathrm{~Hz}, 2 \mathrm{H}), 6.64(\mathrm{t}, J=7.0 \mathrm{~Hz}, 2 \mathrm{H}),(\mathrm{m}, 34 \mathrm{H}), 4.93(\mathrm{~s}, 4 \mathrm{H})$, $4.76(\mathrm{~m}, 2 \mathrm{H}), 4.59(\mathrm{~s}, 4 \mathrm{H}) 3.83(\mathrm{~s}, 2 \mathrm{H}), 3.09(\mathrm{~m}, 2 \mathrm{H}), 2.89$ (m, 2H); IR 1658, 1607, 1517, 1454, $997(\mathrm{~V}=\mathrm{O}) \mathrm{cm}^{-1}$; UV/ Vis $\left(\mathrm{CH}_{2} \mathrm{Cl}_{2}\right.$ soln) $333,370,424 \mathrm{~nm}$; MS $\left(\mathrm{FAB}^{+}\right) \mathrm{m} / \mathrm{z}=1092$ $(\mathrm{MH})^{+}$.

Acknowledgement. This work was supported by Korea Research Foundation (Grant No. 2000-015-DP0262).

\section{References}

I. Cram, D. J. Angew: Chem. Int. Ed. Engl. 1986, 25, 1093; Lehn, J.M. Angew. Chem. Int. Ed. Engl. 1988, 27, 89; Perderson, C. J. Angen. Chem. Int. Ed. Engl. 1988, 27, 1021.

2. Conprehensive Stipramolectitar Chemistry; Lehn, J.-M., Chair ed.; Pergamon Press: Oxford, 1996; Vol, 1-12; Cho, H.-K.; Kim, H.-J.; Lee, K. H.; Hong, J.-I. Bull. Korean Chem. Soc, 2004, 25, 1714.

3. Still, W. C. Acc. Chem, Res. 1996, 29, 155 and references therein.

4. For reviews, See: Linton, B.; Hamilton. A. D. Chen. Rev: 1997. 97,1669 .

5. van Starveren, C. J.; van Eerden, J.; van Veggel, F. C. J. M.; Harkema, S.; Reinhoudt, D. N. J. Am. Chem. Soc. 1988, 110, 4994.

6. Ohlmeyer, M. H. L.; Swanson, R. T.; Dillard, L. W.; Reader, J. C.; Asouline, G.; Kobayashi, R.; Wigler, M.; Still, W. C. Proc. Natl. Acad. Sci. USA 1993, 90 , 10922; Jung, J. E.; Yoon, S. S. Bull. Korean Chem. Soc. 2003, 24, 1525; Lee, K. H.; Yoon, S. S. Bull. Korean Chem. Soc. 2003, 24, 1692.

7. $A A n=$ Any possible combinations of 25 ( $\alpha$ )-amino acids such as Gly, (L)Ala, (D)Ala, (L)Val, (D)Val, (L)Leu, (D)Leu, (L)Phe, (D)Phe, (L)Pro, (D)Pro, (L)Ser(OtBu), (D)Ser(OtBu), (L)Asp (OtBu), (D)Asp(OtBu), (L)Glu(OtBu), (D)Glu(OtBu), (L)Asn (Tr), (D)Asn(Tr), (L)Gln(Tr), (D)Gln(Tr), (L)Lys(Boc), (D)Lys (Boc), (L)His( $\mathrm{Tr}$ ), (D)His(Tr). The number of members in substrates library is $(25)^{3}, 15625$.

8. A total of 15 tag molecules (five tags for AAn) were used to encode the library according to the method reported in reference 6.

9. Yoon, S. S.; Still, W. C. Tetrahedron 1995, 5/, 567. 